\title{
14
}

\section{Biologisch flirten 1 (Hälftenrätsel)}

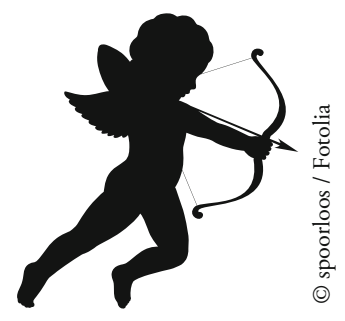

Das Studium bietet neben Mensa, Hausarbeiten und Vorlesungen auch eine hervorragende Gelegenheit, neue Leute kennenzulernen und zu flirten, was das Zeug hält. Doch wie spreche ich die süße Bio-Studentin auf der Uniwiese am besten an? Verbinde die richtigen Herzhälften miteinander und finde heraus, welche biologischen Kosenamen (echte Artnamen) das Herz deines Schwarms höher schlagen lassen.

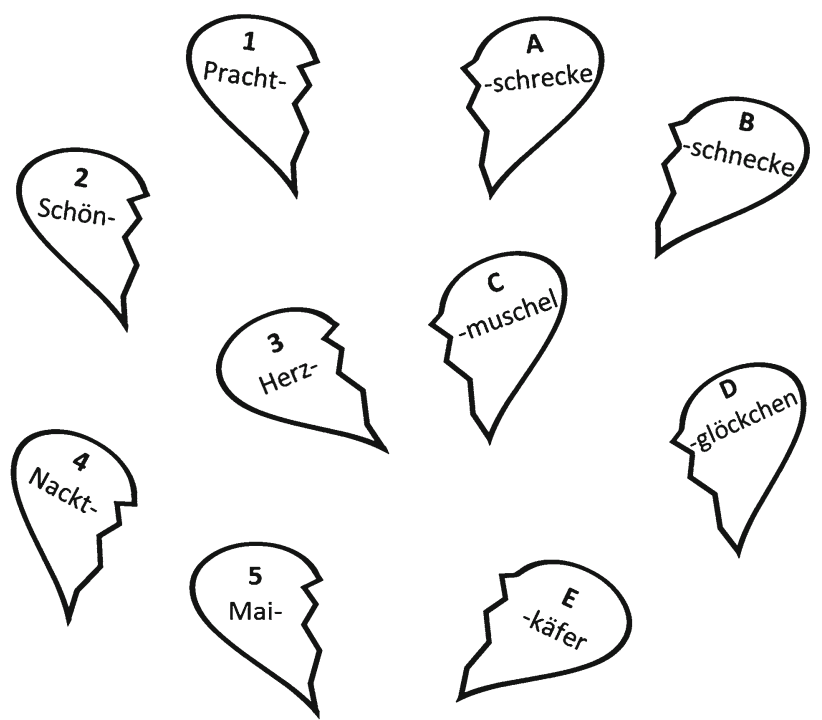

Male deinen Favoriten rot aus. Für die nächste romantische Begegnung bist du nun gewappnet - viel Erfolg!

- Feedback und alternative Kosenamen gerne an: springerraetsel@yahoo.com. 